\title{
Reflections on the Teaching of Architectural Art in Independent Colleges
}

\author{
Yan Huang \\ Xiamen University Tan Kah Kee College \\ Zhangzhou, China
}

\begin{abstract}
The wave of architectural art teaching reform has made the independent college educators begin to consider what adjustments they should make to the teaching of architectural art in the basic education of architecture, so that the architectural art teaching can better adapt to the needs under the new situation, and can play a more active and important role in the independent college architecture major. In order to make the students in the independent college architecture major have broader employment space and better competitive abilities, it is necessary to strengthen the education of architectural art, which is a realistic problem that cannot be underestimated. In response to this situation, how to set up relevant courses and formulate corresponding teaching plans is an issue worthy of consideration by the independent college architectural art teaching teams. In the limited time, students should be guided to organically combine the improvement of art skills and the cultivation of comprehensive art qualities. Through the analysis and reflection of my teaching practice over these years, I believe that we can try to make some breaks through the following approaches: First, update the basic sketch teaching mode and establish the elective course module; Second, update the basic color teaching mode; Third, establish the hand-painted performance technique curriculum system with our own teaching characteristics; Fourth, set up the art elective course module; Fifth, make full use of multimedia resources and develop new teaching ideas. If we want to make the independent college architecture discipline develop more comprehensively and better, and go better and further, we should not only reform and develop the professional design curriculum, but also adjust and improve the architectural art curriculum from many aspects. Art teachers should pay attention to the problems existing or possible to emerge in teaching, analyze them carefully, discuss them in time, and conduct research and exchanges through projects, papers, teaching materials, exhibitions, events, etc., which will also provide references and great impetus for the teaching reform of other related majors in related colleges.
\end{abstract}

Keywords-independent college architecture art teaching; art comprehensive ability; artistic accomplishment; qualified architect

\section{INTRODUCTION}

In the late 1990s, in order to expand the resources of higher education, the state encouraged state-run undergraduate colleges to establish independent colleges in conjunction with social funds. The architecture major in independent colleges was also established in the same period. Since then, it has experienced a period of rapid development. The independent colleges have expanded their enrollment and the teaching system of the major has been gradually improved.
Since the beginning of the 21 st century, The wave of architectural art teaching reform has made the independent college educators begin to consider what adjustments they should make to the teaching of architectural art in the basic education of architecture, so that the architectural art teaching can better adapt to the needs under the new situation, and can play a more active and important role in the independent college architecture major. At present, there are two main viewpoints about art teaching. One is that the art in architecture disciplines is only a tool. It points out that architectural art is for the teaching of architectural design, in the architectural art course, teachers should only teach the content that the architecture major demands for. Art teaching is only a training tool in the teaching system of the architecture major. Another point of view is that art education should have a comprehensive goal. It is believed that as long as it is the art education, it has the responsibility to reflect the overall value of art education, rather than to just show a single value.

From the perspective of the surface, both views seem to be reasonable. If the architecture major in independent colleges wants to go further, and if the colleges want to enable their students to compete with the students trained by the state-run schools and have some competitive abilities when they go to the society, from a more far-reaching perspective, it is necessary to strengthen the architectural art education. More and more teachers are beginning to realize that if students only have skills but lack aesthetic connotation, they will only be regarded as "artisans" and cannot become real architects with aesthetic appeal and independent thoughts and emotions. There are also more and more employers who are aware of the importance of art to architects. They require candidates to provide hand-painted and art works as an important basis for measuring their overall abilities.

Most of the independent colleges' architectural students are enrolled in the major as science students with no art basics If the art education in school is only to improve their art skills, this kind of education model is not completely successful. In order to make the students in the independent college architecture major have broader employment space and better competitive abilities, it is necessary to strengthen the education of architectural art, which is a realistic problem that cannot be underestimated. In response to this situation, how to set up relevant courses and formulate corresponding teaching 
plans is an issue worthy of consideration by the independent college architectural art teaching teams.

\section{UPDATE OF THE BASIC SKETCH TEACHING ModE}

Let the basic sketch teaching go out of the traditional simple copying and painting mode, and guide the students to the architectural art teaching system that complements the architectural design discipline. This is a good attempt to reform the architectural art teaching and it has adapted to the requirements for training new talents. For independent colleges, the quality of students and the future social survival abilities of students are important indicators directly related to the development of the colleges. The independent colleges' architectural sketch teaching should not only meet the requirements of the national architectural disciplines for the cultivation of students' artistic abilities, but also reflect the colleges' own characteristics and form their own advantages. In the design of sketch teaching, I think we can try the following ways:

In the first semester, teachers should focus on training students' ability to split and restructure the structures from simple geometric shapes to complex geometric shapes to architectural components and architectural models. And train students' ability to analyze the light and shadow of parts and wholes. In the second semester, students should be mainly trained to sketch the indoor and outdoor spaces and landscapes. On the basis of not reducing the skill level that students can reach from participating in the traditional courses, the sketch training of fruits, vegetables and other still things as well as plaster heads and statues can be skipped, and the limited class time should be concentrated on the sketch training of shapes and spaces closely related to architectural design. So that the students' acuity of visual images and fit of hands and brains can be strengthened, which will also enable students to establish spatial perspective consciousness, threedimensional composition consciousness and enhance aesthetic taste.

\section{UPdATE OF THE BASIC COLOR TEACHING MODE}

In the multimedia era, computer technologies have been widely used in various disciplines, the architecture discipline is no exception. If students want to use computer software to accurately pick and match colors, they must have certain color perception and color acuity. Such a new situation requires the color teaching of architectural art to not only teach students relevant color knowledge, train students' basic art performance techniques, but also guide students to establish their color aesthetic systems within a limited period. Therefore, color teaching reform is also worth exploring.

The traditional architectural color teaching mode mostly trains students' painting techniques through making them sketch things, how to draw and how to draw like the real things is the focus of traditional teaching. Although long-term training allows students to recognize colors and master some color knowledge, and enables students to master a kind of expression skills and draw their pictures freely, in the face of the current situation of students' lack of art foundation and schools' lack of class hours, this mode will obviously make its effects slowly. It is no longer suitable for the new situation.
The art color teaching as the support for the architectural design courses, in order to get comprehensive effects, it is necessary to meet three basic requirements: 1 . Students can master the color rules and use them freely; 2. Students can have certain color work performance ability; 3 . It can improve the color literacy of the students.

\section{ESTABlishing THE HAND-PAINTED PERFORMANCE TECHNIQUE COURSE SYSTEM WITH THE COLLEGE's OWN TEACHING CHARACTERISTICS}

The hand-painted performance technique course has distinct professional features. Different from sketching, coloring and other art basic courses, it serves the architectural design schemes, and the works of it are hand-painted renderings. Only under the premise of mastering the basic knowledge of art, can students work out good hand-painted renderings. The hand-painted renderings and the art of painting have a common side. They are the image representation of the "programs" as well as the artistic works. They are both scientific and artistic, and are the unities of the two characteristics. The hand-painted performance technique course must allow students to master sketching techniques, accurately express the relationship between architecture and space, and try to make their own drawings real and textured. This course can train students' design, styling, color expression abilities and comprehensive ability to express the overall space of the pictures.

At present, there are performance technique courses in many architecture majors. Many schools have also incorporated computer graphics into the performance technique curriculum system and have reduced the class hours and course hours of hand-painted performance technique training. I believe that the hand-painting ability is a basic quality of design expression, a good hand-painted performance basis can improve the drawing effect of computer graphics, and can enhance students' overall ability of architectural design, which needs to be emphasized in the performance technique curriculum system.

Through the analysis of the employment situation of the independent college architecture major students after their graduation, it is found that in order to make students have stronger social competitiveness, it is necessary to improve their ability to express by hand. Among them, the training of hand-painted performance techniques needs to be strengthened.

We can explore a unique hand-painted performance technique teaching system:

- Arrange the architectural design teachers and the art teachers to coordinate in teaching, give full play to the characteristics of the design teachers and the art teachers, closely combine the logical thinking with the image thinking, make use of the architectural design teachers' systematic analysis ability of the architectural design and the art teachers' acuity of perspective, structure, modeling and color, and make the two kinds of teachers complement each other, constantly discuss and conduct practice with each other, generating sparks in the collisions, and guiding 
students to draw performance technique hand-painted renderings with distinctive characteristics.

- Train students to master the common performance techniques of various design renderings, such as gouache painting, watercolor painting, pen pastel, marker stroke, etc., enable students to fully reflect the design intent and the image effect using these techniques, and enhance the students' performance literacy.

- $\quad$ Try to add architectural design elements with regional characteristics, and guide students to draw architectural performance renderings with regional characteristics, reflecting the local architectural style.

- Improve the teachers' own abilities, make a more systematic teaching division for architectural design teachers and art teachers, form a characteristic teaching system, and try to write professional teaching materials that meet the requirements of the independent college architecture major hand-painted performance technique course, promoting the development and improvement of the curriculum.

\section{The Establishment OF THE ART EleCtive COURSE MODULE}

Since the total class hours and hours of the art foundation courses are limited, in order to enable students to contact with and master the art related knowledge more comprehensively and systematically, the colleges should not only set up the art foundation courses such as sketch, color, and performance techniques, but also set up a large number of art elective courses to improve students' aesthetic ability. Art teachers can offer a variety of art elective courses, such as Chinese and foreign art histories, Chinese and foreign design histories, Chinese painting, oil painting, printmaking, sculpture, calligraphy, handicraft, engraving, pen drawing, color lead painting, watercolor painting, gouache, plane composition, three-dimensional composition and other courses. These courses are distributed in every semesters, and students are free to choose the courses and obtain the credits required for the corresponding elective module. Through the selection and study of the courses, students can not only improve their skill level, but also enhance their comprehensive art knowledge structure and aesthetic quality. There are theoretical parts as well as practical parts in the art elective courses offered to the students, which will run through the five-year undergraduate teaching stage. These courses are based on the basic courses of architectural art, and the two kinds of courses complement each other, achieving a more comprehensive teaching effect.

\section{MaKing Full USE OF MUltimedia RESOURCES AND DEVELOPING NEW IDEAS FOR TEACHING}

In recent years, with the development of the network, and digital and communication technologies, new media has been integrated into our daily teaching. At present, the most involved teaching modes in teaching are micro-courses, MOOCs and flipped classrooms. These three teaching modes are considered by most people to be the best and most appropriate teaching models which have combined new media and teaching. Under the new situation, architectural art teaching should also make some useful attempts: make full use of new technologies, use new media, create flexible teaching forms, and participate in the production of microcourses, MOOCs and flipped classrooms.

"Micro-course" refers to the course with videos as the main carrier. The video records the whole process of teaching activities carried out for a certain knowledge point (the key point, the difficult point, the doubtful point) or teaching link in the teacher's in-class or off-class teaching process. The micro-course starts from the details of knowledge, visualizes the abstract architectural art knowledge, and makes the boring knowledge lively and interesting through the production of visual carriers such as videos, mobilizing the students' interest in learning, allowing students to understand the knowledge thoroughly and know the whole process of painting, and enhancing their initiative of learning.

"MOOCs" are different from traditional classes. There is a tens of thousands of students studying in a MOOC. In this mode, students can be interested in learning. Any student who wants to study can learn the courses online on their own, regardless of time and space, regardless of nationality. Just using an E-mail address, you can log in. The production of architectural art MOOCs can allow each student to access the relevant courses through the Internet, and can strengthen the academic exchange of the subject in the country and the world.

"Flipped Classrooms" re-adjust the in-class and off-class time and transfer the decision-making power of learning from the teacher to the student. In this mode of teaching, teachers no longer take up the in-class time to teach, it is required that students learn the content of the course independently after class, teachers use collaborative methods to meet the needs of students and enable them to obtain more realistic learning through practice. The biggest feature of flipped classrooms is to take the students as the main body of the classes, and at the same time give full play to the leading role of the teachers. In the flipped classrooms of architectural art, the teacher mainly plays a guiding role to help students discover their problems in painting, and let the students use the digital platforms such as the Internet to learn and communicate independently and to solve problems. Such a teaching mode can greatly mobilize students' enthusiasm for learning and cultivate students' selflearning ability in the subject of architectural art.

\section{CONCLUSION}

Architectural art has the characteristics of rational thinking, scientific means, artistic aesthetics, and compatibility of arts and sciences. Through the reform of the art curriculum system, it is expected that the curriculum can achieve the purpose of cultivating and improving students' observation ability, expressive force and esthetic judgment, edifying and enriching students' thoughts and feelings, and developing students' creativity. Of course, if the independent college architecture discipline wants to develop more comprehensively and better, and go better and further, it is needed to adjust and improve the architectural art curriculum in coordination with the reform and development of professional design courses. Art teachers should pay attention to the problems that exist or may occur in the teaching process 
at any time, conduct detailed analysis and timely discussion, and make exchanges and researches through the projects, papers, topics, exhibitions and other means, which will also provide great reference and driving force for the teaching reform of other related majors in other colleges.

\section{REFERENCES}

[1] Jin Yi. Hand-painted rendering basic training series - architectural performance facsimiles. Liaoning: Liaoning Fine Arts Publishing House; 1st edition. March 2013.

[2] Jing Chengyi. Masters of painting altar--Master architectural sketch selection. Liaoning: Liaoning Fine Arts Publishing House; 1st edition. December 2014.

[3] Li Jie. Easy hand-painted drawings---Architectural rendering performance techniques. Shanghai: Shanghai People's Fine Arts Publishing House. 1st edition. April 2015.

[4] Yu Xiang. Architectural sketch. Beijing: Mechanical Industry Press; 2nd edition. August 2010.

[5] Zhou Hongzhi. Architectural Art - Watercolor. Beijing: China Electric Power Press; 2nd Edition. June 2012.

[6] Luo Kezhong. Design and hand-painted series - pen light color architectural landscape techniques. Liaoning: Liaoning Fine Arts Publishing House; May 2014.

[7] Wu Xiaoqi, Liang Yu, Yu Xiaoxue, Zhang Tianzhen. Hard-tipped pen line drawing and light color techniques. Hangzhou: China Academy of Art Press; 1st edition. March 2005.

[8] Zeng Fanren. On the Modern Significance of Aesthetic Education. Journal of Shandong University (Philosophy Edition). 1997: pp.25-27.

[9] An Ning. Color principles and color compositions. Hangzhou: China Academy of Art Press; 1st edition. May 1999. 